\section{AB0752 DRUG RETENTION AND REMISSION RATES IN 14,261 BIOLOGIC-NAIVE PATIENTS WITH PSORIATIC ARTHRITIS STARTING TNF INHIBITOR TREATMENT IN ROUTINE CARE - RESULTS FROM 12 REGISTRIES IN THE EUROSPA RESEARCH COLLABORATION}

${ }^{1}$ Cecilie Heegaard Brahe", Lykke Ørnbjerg ${ }^{1}$, Lennart T.H. Jacobsson ${ }^{1}$, Michael Nissen ${ }^{1}$, Eirik Kristianslund ${ }^{1}$, Herman Mann ${ }^{1}$, Maria Jose Santos ${ }^{1}$, Manuel Pombo-Suarez ${ }^{1}$, Dan Nordström ${ }^{1}$, Ziga Rotar ${ }^{1}$, Björn Gudbjornsson ${ }^{1}$, Fatos Onen ${ }^{1}$, Catalin Codreanu', Ulf Lindström ${ }^{1}$, Burkhard Moeller ${ }^{1}$, Joe Sexton ${ }^{1}$, Karel Pavelka' ${ }^{1}$, Anabela Barcelos ${ }^{1}$, Carlos Sánchez-Piedra ${ }^{1}$, Kari Eklund $^{1}$, Matija Tomsic ${ }^{1}$, Thorvardur Jon Love ${ }^{1}$, Gerçek Can $^{1}$, Ruxandra lonescu ${ }^{1}$, Anne Gitte Loft ${ }^{1}$, Marleen van de Sande ${ }^{1}$, Irene van der Horst-Bruinsma ${ }^{1}$, Gary Macfarlane ${ }^{1}$, Florenzo lannone ${ }^{1}$, Lise Hyldstrup ${ }^{1}$, Niels Steen Krogh ${ }^{1}$, Mikkel Ǿstergaard ${ }^{1}$, Merete L. Hetland ${ }^{1}$.

${ }^{1}$ EuroSpA Research Collaboration, On behalf of the DANBIO (Denmark), ARTIS (Sweden), SCQM (Switzerland), NOR-DMARD (Norway), ATTRA (Czech Republic), Reuma.pt (Portugal), BIOBADASER (Spain), ROB-FIN (Finland), biorx.si (Slovenia), ICEBIO (Iceland), TURKBIO (Turkey), RRBR (Romania), ARC (Netherlands), BSRBR-AS (United Kingdom), GISEA (Italy), Denmark

Background: The efficacy of Tumour Necrosis Factor Inhibitor (TNFi) in patients with psoriatic arthritis (PsA) has been investigated in randomized controlled trials (RCTs) with strict inclusion and exclusion criteria. Patients treated in routine care are more heterogeneous and only $\approx 20-30 \%$ of patients receiving TNFi in routine care would have been eligible to be enrolled in the RCTs ${ }^{1}$. This emphasizes the need for real-world observational data as a valuable supplement to RCTs. Studying large patient groups from several European countries would increase the external validity of the results.

Objectives: To investigate Tumour Necrosis Factor inhibitor (TNFi) retention rates at 12 months (primary objective), 6 and 24 months, and remission rates at the same time-points in biologic-naïve patients with PsA from the EuroSpA Collaboration.

Methods: Prospectively collected data on PsA patients from 12 European registries were uploaded through the secure Virtual Private Network pipelines to the EuroSpA server, and pooled. Baseline characteristics were investigated with non-parametric descriptive statistics. TNFi retention rates (Kaplan-Meier statistics), and 28-joint count Disease Activity Score (DAS28) $<2.6$ and 28 joint Disease Activity index for Psoriatic Arthritis (DAPSA28) $\leq 4$ were calculated, including LUNDEX adjustment ${ }^{2}$. For patients initiating $1^{\text {st }}$ TNFi after January $1^{\text {st }} 2009$, the following subcohorts were also studied: patients known to be fulfilling CIASsification for Psoriatic ARthritis (CASPAR) criteria and patients with one or more swollen joints (swollen joint count $(S J C) \geq 1$ ) at baseline.
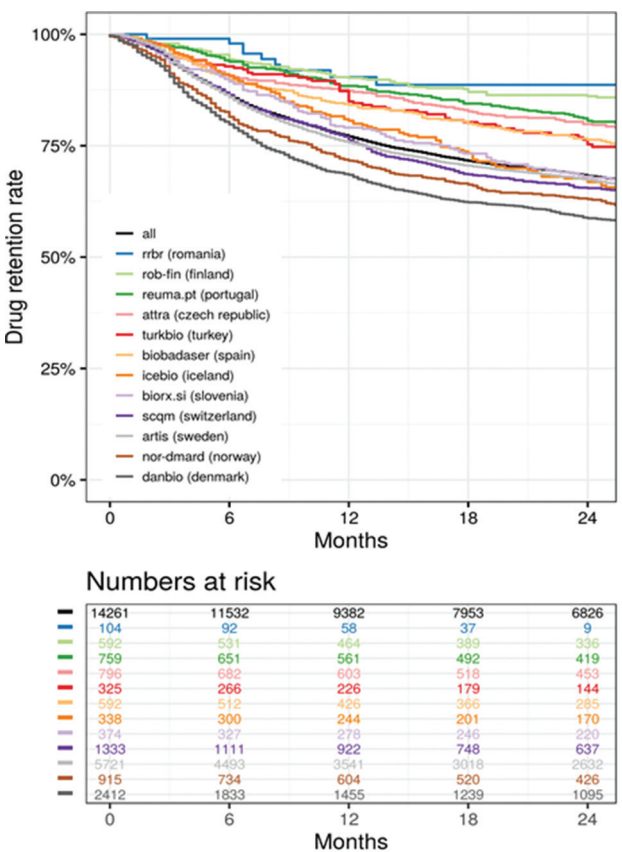
Figure: Kaplan-Meier curres (top) showing drug retention rates up to 24 months for
pooled data and per register. The table (bottom) shows the number of patients who pooled data and per register. The table (bottom) shows the
were still being treated at the corresponding time points.

\begin{tabular}{|c|c|c|c|c|c|c|}
\hline Infliximab & 3,069 & $22 \%$ & \multicolumn{2}{|c|}{$12 \%$} & \multicolumn{2}{|r|}{$18 \%$} \\
\hline Etaner cospt & 4,788 & $34 \%$ & \multicolumn{2}{|c|}{$25 \%$} & \multicolumn{2}{|r|}{$31 \%$} \\
\hline Adalimumab & 4,364 & $31 \%$ & \multicolumn{2}{|c|}{$36 \%$} & \multicolumn{2}{|r|}{$32 \%$} \\
\hline Certolizumab & 524 & $4 \%$ & \multicolumn{2}{|c|}{$5 \%$} & \multicolumn{2}{|r|}{$5 \%$} \\
\hline Golimumab & 1.516 & $11 \%$ & \multicolumn{2}{|c|}{$22 \%$} & \multicolumn{2}{|r|}{$15 \%$} \\
\hline DAS28 & 9,450 & $4.3(3.45 .1)$ & \multicolumn{2}{|c|}{$4.4(3.5-5.3)$} & \multicolumn{2}{|c|}{$4.5(3.8-5.2)$} \\
\hline DAPSA28 & 8.717 & $\begin{array}{c}26.7 \\
(17.6-39.2)\end{array}$ & \multicolumn{2}{|c|}{$\begin{array}{c}28.4 \\
(18.4-42.2)\end{array}$} & \multicolumn{2}{|c|}{$29.9(21.5-41.2)$} \\
\hline CRP, mg/L & 11,138 & $7(3-17)$ & \multicolumn{2}{|c|}{$8(3-17)$} & \multicolumn{2}{|c|}{$7(3-18)$} \\
\hline $\operatorname{SSC}(0-28)$ & 10,777 & $3(1-6)$ & \multicolumn{2}{|c|}{$3(1-7)$} & \multicolumn{2}{|r|}{$4(2-7)$} \\
\hline $\operatorname{TJC}(0-28)$ & 10,764 & $5(2-9)$ & \multicolumn{2}{|c|}{$5(2-10)$} & \multicolumn{2}{|r|}{$6(3-10)$} \\
\hline $\operatorname{SJC}(0-66)$ & 3,815 & $4(1-7)$ & \multicolumn{2}{|c|}{$4(2-8)$} & \multicolumn{2}{|r|}{$5(3-8)$} \\
\hline \multirow[t]{2}{*}{ TJC (0-68) } & 4,655 & $8(4-14)$ & & -14) & & (5-15) \\
\hline & \multicolumn{6}{|c|}{ Retention rates } \\
\hline 6 months $(95 \% \mathrm{Cl})$ & \multirow{2}{*}{\multicolumn{2}{|c|}{$86 \%(86-87 \%)$}} & \multicolumn{2}{|c|}{$88 \%(87-90 \%)$} & \multicolumn{2}{|c|}{$85 \%(84-86 \%)$} \\
\hline 12 months $(95 \% \mathrm{Cl})$ & \multirow{2}{*}{\multicolumn{2}{|c|}{$\begin{array}{l}77 \%(76-78 \%) \\
68 \%(67-69 \%)\end{array}$}} & \multicolumn{2}{|c|}{$78 \%(77-80 \%)$} & \multirow{2}{*}{\multicolumn{2}{|c|}{$\begin{array}{l}76 \%(74-77 \%) \\
67 \%(65-68 \%)\end{array}$}} \\
\hline \multirow[t]{3}{*}{24 months ( $95 \% \mathrm{Cl}$ ) } & & & $69 \%$ & 7-71\%) & & \\
\hline & \multicolumn{6}{|c|}{ Remission rates } \\
\hline & Crude $e^{* * *}$ & LUNDEX adjusted & Crude & 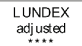 & Crude & $\begin{array}{l}\text { LUNDEX } \\
\text { adjusted } \cdots\end{array}$ \\
\hline $\begin{array}{l}\text { DAS28 remission at } 6 \\
\text { months }\end{array}$ & $56 \%$ & $45 \%$ & $59 \%$ & $49 \%$ & $55 \%$ & $43 \%$ \\
\hline $\begin{array}{l}\text { DAS28 remission at } 12 \\
\text { months }\end{array}$ & $61 \%$ & $40 \%$ & $65 \%$ & $43 \%$ & $63 \%$ & $38 \%$ \\
\hline $\begin{array}{l}\text { DAS28 remission at } 24 \\
\text { months }\end{array}$ & $65 \%$ & $31 \%$ & $68 \%$ & $32 \%$ & $69 \%$ & $29 \%$ \\
\hline $\begin{array}{l}\text { DAPSA28 remi ssion at } 6 \\
\text { months }\end{array}$ & $27 \%$ & $22 \%$ & $30 \%$ & $25 \%$ & $27 \%$ & $21 \%$ \\
\hline $\begin{array}{l}\text { DAPSA28 remission at } \\
12 \text { months }\end{array}$ & $30 \%$ & $20 \%$ & $33 \%$ & $22 \%$ & $32 \%$ & $20 \%$ \\
\hline $\begin{array}{l}\text { DAPSA28 remission at } \\
24 \text { months }\end{array}$ & $33 \%$ & $16 \%$ & $34 \%$ & $16 \%$ & $34 \%$ & $14 \%$ \\
\hline
\end{tabular}

Results: Overall, 14,261 patients with PsA initiated a $1^{\text {st }}$ TNFi. Baseline characteristics of the pooled population are shown in the Table.

The median 12 -month retention rate $(95 \% \mathrm{Cl})$ was $77 \%(76-78 \%)$, ranging from $68-90 \%$ across registries (Figure). Overall, DAS28/DAPSA28 remission rates at 6 months were 56\%/27\% (LUNDEX-adjusted: $45 \% / 22 \%$ ). In patients initiating a $1^{\text {st }} \mathrm{TNFi}$ after 2009 with registered fulfillment of CAS PAR criteria $(n=1,980)$ or registered $\geq 1$ swollen joint at baseline $(n=5,803)$, the retention rates and remission rates were similar to those found overall (Table).

Conclusion: Approximately half of $>14,000$ patients with PsA who initiated $1^{\text {st }}$ TNFi treatment in routine care were in DAS28-remission after 6 months, and three out of four were still on the drug after 1 year.

\section{REFERENCES}

[1] Clin Exp Rheumatol, 2018, 36(6):1068-1073

[2] Arthritis Rheum, 2006, 54(2): 600-6

Acknowledgement: Novartis Pharma AG and IQVIA for supporting the EuroSpA collaboration.

Disclosure of Interests: Cecilie Heegaard Brahe Grant/research support from: Unrestricted grant: Novartis, Lykke Ørnbjerg Grant/research support from: Unrestricted grant: Novartis, Lennart T.H. Jacobsson Consultant for: LJ has received lecture and consulting fees from Pfizer, Abbvie, Novartis, Eli-Lily and Janssen, Michael Nissen Consultant for: AbbVie, Lilly, Novartis, and Pfizer, Eirik kristianslund: None declared, Heřman Mann Consultant for: Pfizer, Eli Lilly, Sanofi, Speakers bureau: AbbVie, Roche, Pfizer, MSD, Eli Lilly, Sanofi, Maria Jose Santos: None declared, Manuel Pombo-Suarez: None declared, Dan Nordström Grant/research support from: MSD, Pfizer, Consultant for: AbbVie, BMS, MSD, Novartis, Roche, Pfizer, UCB, Speakers bureau: Novartis, UCB, Ziga Rotar: None declared, Björn Gudbjornsson: None declared, Fatos Onen: None declared, Catalin Codreanu: None declared, Ulf Lindström: None declared, Burkhard Moeller Consultant for: Swissmedic Human Medicines Expert Committee Member (regulatory agency), Joe Sexton: None declared, Karel Pavelka: None declared, Anabela Barcelos: None declared, Carlos Sánchez-Piedra: None declared, Kari Eklund: None declared, Matija Tomsic: None declared, Thorvardur Jon Love Consultant for: Received reimbursment from Celgene for speaking about guidelines for the treatment of psoriatic arthritis, Gerçek Can: None declared, Ruxandra lonescu: None declared, Anne Gitte Loft: None declared, Marleen van de Sande Grant/research support from: van Janssen, Novartis, Eli Lily, Consultant for: Novartis and Abbvie, Irene van der Horst-Bruinsma Grant/research support from: MSD, Pfizer, AbbVie, Consultant for: Abbvie, UCB, MSD, Novartis, Speakers bureau: BMS, AbbVie, Pfizer, MSD, Gary Macfarlane Grant/research support from: Have received research grants (not current) from Abbvie and Pfizer. 
Have received research grants (not current) from the British Society for Rheumatology, who received the funds from Abbive, Pfizer and UCB. Have received research grant (current) from the British Society for Rheumatology, who received the funds from Celgene., Florenzo lannone Consultant for: $F$ lannone has received consultancy fees and/or speaker honoraria from Pfizer, AbbVie, MSD, BMS, Novartis, Lilly, UCB outside this work, Speakers bureau: $F$ lannone has received consultancy fees and/or speaker honoraria from Pfizer, AbbVie, MSD, BMS, Novartis, Lilly, UCB outside this work, Lise Hyldstrup: None declared, Niels Steen Krogh: None declared, Mikkel Ǿstergaard Grant/research support from: Abbvie, Celgene, Centocor, Merck, Novartis, Consultant for: Abbvie, BMS, Boehringer-Ingelheim, Celgene, Eli Lilly, Hospira, Janssen, Merck, Novartis, Novo, Orion, Pfizer, Regeneron, Roche, and UCB, Speakers bureau: Abbvie, BMS, Boehringer-Ingelheim, Celgene, Eli Lilly, Hospira, Janssen, Merck, Novartis, Novo, Orion, Pfizer, Regeneron, Roche, and UCB, Merete L. Hetland Grant/research support from: BMS, MSD, AbbVie, Roche, Novartis, Biogen, Pfizer, Consultant for: Eli Lilly, Speakers bureau: Orion Pharma, Biogen, Pfizer, CellTrion, Merck, Samsung Bioepis DOI: 10.1136/annrheumdis-2019-eular.1800

\section{AB0753 COMPARING COMPOSITE MEASURES OF DISEASE ACTIVITY IN PSORIATIC ARTHRITIS: RESULTS FROM A RANDOMIZED PHASE 2 TRIAL WITH GUSELKUMAB}

${ }^{1}$ Philip Helliwell ${ }^{*}$, Atul Deodhar ${ }^{2}$, Alice B. Gottlieb ${ }^{3}$, Wolf-Henning Boehncke ${ }^{4}$, Xie L. Xu ${ }^{5}$, Stephen $\mathrm{Xu}^{5}$, Yuhua Wang ${ }^{5}$, Elizabeth C. Hsia ${ }^{5,6}$, Dafna D. Gladman ${ }^{7}$, Christopher T. Ritchlin ${ }^{8} .{ }^{1}$ University of Leeds, Leeds, United Kingdom; ${ }^{2}$ Oregon Health and Science Univ, Portland, United States of America; ${ }^{3}$ Icahn School of Med at Mount Sinai, New York, United States of America; ${ }^{4}$ Geneva University Hospitals and Dept of Pathology and Immunol, Geneva, Switzerland; ${ }^{5}$ Janssen Research and Development, LLC, Spring House, United States of America; ${ }^{6}$ Univ of Pennsylvania, Phila, United States of America; ${ }^{7}$ University of Toronto, Krembil Research Institute, Toronto, Canada; ${ }^{8}$ University of Rochester Medical Center Rochester, United States of America

Background: Psoriatic ArthritiS Disease Activity Score (PASDAS), GRAppa Composite scorE (GRACE) Index, modified Composite Psoriatic Disease Activity Index (mCPDAI), and Disease Activity Index for PSoriatic Arthritis (DAPSA) are composite indices recently developed to assess disease activity in psoriatic arthritis (PsA).1,2 Guselkumab (GUS) is a monoclonal antibody targeting interleukin-23 that has demonstrated efficacy in a phase 2 PsA trial.3

Objectives: To compare the effect of GUS on disease activity in psoriatic arthritis (PsA) as measured by these composite indices.

Methods: In this Phase-2 trial, patients with active PsA $>3$ tender, $>3$ swollen joints, C-reactive protein $\geq 3 \mathrm{mg} / \mathrm{L}, \geq 3 \%$ body surface area) were randomized $2: 1$ to subcutaneous GUS $100 \mathrm{mg}(n=100)$ or placebo (PBO, $\mathrm{n}=49$ ) at $\mathrm{Wk0}, \mathrm{Wk} 4$, and every 8 wks through Wk44. At Wk16, patients with $<5 \%$ improvement in swollen plus tender joints could early-escape (EE) to open-label ustekinumab. Patients continuing PBO crossed-over to receive GUS 100mg at Wks 24/28/36/44 (PBO to GUS). PsA composite indices PASDAS, GRACE, mCPDAI, and DAPSA were analyzed using lastobservation-carried-forward for missing/post-EE data through Week24. Instruments were validated using SF-36 physical component summary (PCS) score as an anchor. Sensitivity was assessed via standardized mean differences (SMDs), effect size (ES) and standardized response means (SRMs).

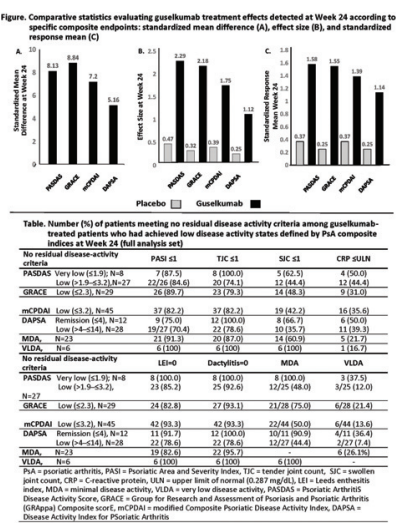

Results: Changes in SF-36 PCS score were consistent with disease activity states at Wk24 for each PsA composite index in guselkumab- treated patients. The SMD, ES and SRM indicated that guselkumab elicited a substantial effect in treating the diverse manifestations of PsA compared with placebo, regardless of composite index employed (Figure) PASDAS and GRACE indices appeared to be more sensitive than mCPDAI and DAPSA in detecting changes upon treatment and distin guishing guselkumab treatment effects relative to placebo. Residual disease activities among guselkumab-treated patients who achieved low disease activity at Week24 based on each PsA composite index are summarized in the Table.

Conclusion: Regardless of the PsA-specific composite index employed, GUS significantly improved disease activity and achieved clinically meaningful therapeutic targets such as low/minimal disease activity or remission. PASDAS and GRACE indices were more sensitive than mCPDAI and DAPSA in detecting changes in disease activity by guselkumab treatment.

\section{REFERENCES}

[1] Helliwell PS, et al. JRheumatol 2014;41:1212-1217.

[2] Scholes MM, et al. AnnRheumDis 2016;75:811-818.

[3] Deodhar A, et al. Lancet 2018;391: 2213-24.

Disclosure of Interests: Philip Helliwell Grant/research support from: Paid to charity: from AbbVie, Janssen and Novartis, Consultant for: Paid to charity: from AbbVie, Amgen, Pfizer, and UCB and Celgene. Paid to self: from Celgene and Galapagos, Atul Deodhar Grant/research support from: AbbVie, Amgen, Eli Lilly, GSK, Janssen, Novartis, Pfizer, and UCB, Consultant for: AbbVie, Amgen, BMS, Eli Lilly, Janssen, Novartis, Pfizer, and UCB, Alice B Gottlieb Grant/research support from: PI: Incyte Corporation, Janssen-Ortho Inc., Lilly ICOS LLC, Novartis, UCB, XBiotech, Consultant for: AbbVie, Dermira, Incyte Corporation, Lilly ICOS LLC, Novartis, Sun Pharmaceutical Industries Ltd., Avotres (unpaid), XBiotech (unpaid), Speakers bureau: AbbVie, Eli Lilly and Company, Janssen Biotech; advisory board: Bristol-Myers Squibb, Celgene Corporation, Janssen Biotech, Janssen-Ortho Inc., LEO Pharma, Novartis, UCB, Wolf-Henning Boehncke Consultant for: Pfizer Inc, Speakers bureau: Pfizer Inc, Xie L Xu Employee of: Employee of Janssen Research \& Development, LLC, Stephen Xu Employee of: Employee of Janssen Research \& Development, LLC, Yuhua Wang Employee of: Employee of Janssen Research \& Development, LLC, Elizabeth C Hsia Employee of: Employee of Janssen Research \& Development, LLC, Dafna D Gladman Grant/research support from: AbbVie, Amgen, Celgene, Lilly, Novartis, Pfizer, and UCB, Consultant for: AbbVie, Amgen, BMS, Celgene, Galapagos, Gilead, Janssen, Lilly, Novartis, Pfizer, and UCB, Christopher T. Ritchlin Grant/research support from: AbbVie, Amgen, UCB Pharma, Consultant for: AbbVie, Amgen, Lilly, Novartis, Pfizer, UCB Pharma

DOI: 10.1136/annrheumdis-2019-eular.643

\section{AB0754 1 CLINICALLY MEANINGFUL IMPROVEMENT IN SKIN AND NAIL PSORIASIS IN BIO-NAÏVE ACTIVE PSORIATIC ARTHRITIS PATIENTS TREATED WITH INTRAVENOUS GOLIMUMAB: RESULTS THROUGH WEEK 52 FROM A PHASE-3 STUDY}

${ }^{1}$ M Elaine Husni", Philip J. Mease ${ }^{2}$, Soumya D. Chakravarty ${ }^{3,4}$, Shelly Kafka ${ }^{3}$ Diane D. Harrison ${ }^{5}$, Dennis Parenti ${ }^{3}$, Lilianne Kim ${ }^{5}$, Kim Hung Lo ${ }^{5}$, Elizabeth C. Hsia ${ }^{5,6}$, Arthur Kavanaugh $7 .{ }^{1}$ Cleveland Clinic, Cleveland, United States of America; ${ }^{2}$ Swedish Med Center and U of Wash School of Med, Seattle, United States of America; ${ }^{3}$ Janssen Scientific Affairs, LLC, Horsham, United States of America; ${ }^{4}$ Drexel University College of Med, Philadelphia, United States of America; ${ }^{5}$ Janssen Research and Development, LLC, Spring House, United States of America; ${ }^{6}$ Univ of Penn Medical Center, Phila, United States of America; ${ }^{7}$ Univ of CA San Diego, San Diego, United States of America

Background: GO-VIBRANT is a Phase 3 trial of intravenous (IV) golimumab (GLM) in adult patients (pts) with active psoriatic arthritis (PsA). Clinically meaningful improvements in skin and nail psoriasis (PsO) and in Dermatology Life Quality Index (DLQI) that were significantly greater than placebo (PBO) at weeks (wks) 14 \& 24 were previously reported.1 Objectives: To evaluate improvement in skin and nail PsO and DLQI with IV GLM through wk52.

Methods: Adult bio-naïve PsA pts with active disease $(\geq 5$ swollen \& tender joints, CRP $\geq 0.6 \mathrm{mg} / \mathrm{dL}$, active plaque psoriasis or documented history), despite treatment w/csDMARDs \&/or NSAIDs, were randomized to IV GLM $2 \mathrm{mg} / \mathrm{kg}$ at wks $0 / 4$ \& every 8 wks thereafter or PBO at wks $0 /$ $4 / 12 / 20$ with crossover to GLM at wk24. Pts with $\geq 3 \%$ body surface area (BSA) psoriasis at baseline (BL) were assessed using Psoriasis Area and Severity Index (PASI, 0-72) of $75 / 90 / 100 \%$ improvement scale, 